\title{
MODEL PENYELESAIAN SENGKETA DALAM PANDANGAN ANTROPOLOGI HUKUM
}

\author{
RIGO ASMAR PUTRA \\ rigooasmarputraa@gmail.com \\ 2010003600388 \\ UNIVERSITAS EKASAKTI
}

\section{A. PENDAhuluan}

Beberapa pendekatan antropologi hukum yang pada dasarnya mengkaji hukum sebagai sebuah kenyataan yang diterapkan oleh masyarakat (law in action), termasuk prospeknya dalam "memotret" gejala hukum di era reformasi. Hasil penelitian ini menunjukkan bahwa norma-norma state law disahkan oleh teks resmi (oleh negara) berbeda dengan norma-norma folk law yang disahkan melalui ketaatan akan seperangkat kebiasaan. Norma-norma state law disatukan melalui asal mula logikal dari suatu norma dasar yang berbeda dengan norma-norma folk law yang disatukan oleh ketaatan di dalam suatu masyarakat. State law sebagai proses dari pengadilan negara berbeda dengan folk law sebagai proses penyelesaian sengketa di luar lingkup negara. Lalu dari proses sejarahnya pun kedua sistem hukum tersebut dapat dipisahkan, yakni yang state law lazimnya berasal dari pengambilan (sebagian atau seluruhnya) dari sistem hukum kolonial dan selanjutnya mungkin dikembangkan. Konsep "unifikasi hukum" telah diterapkan cukup lama di NKRI. Berbagai peraturan perundangan kemudian dibuat sesuai dengan konsepsi di atas. Sekedar contoh adalah: UU Perkawinan (UU No. 1/74), seperti diketahui UU ini ditujukan untuk menggantikan enam sistem hukum lain yang tadinya berlaku untuk pelbagai golongan masyarakat di tanah air. Tujuan unifikasi peraturan perundangan tersebut adalah agar terjadi pelaksanaan hukum yang terkoordinasi, lebih tertib dan kinerjanya diharapkan meningkat (Sunaryati Hartono, 1993; 9). Lalu, pertanyaannya apakah kenyataannya demikian? Perdebatan untuk jawaban itupun setidaknya bisa terpilah dua, yang satu berkenaan dengan susunan yuridis normatifnya, satunya 
lagi mengenai efektivitas peraturannya di lapangan. Namun, rata-rata di antara kita akan menyatakan bahwa kondisi dan kinerja hasil unifikasi hukum belum juga mengalami perbaikan signifikan. Pada saat yang sama, bahkan telah berlangsung jauh lebih lama terdapat pelbagai sistem hukum dari masyarakat dan kebudayaan-kebudayaan lain (the other cultures) selain state law (hukum negara). Masyarakatnya mempertahankan sistem-sistem hukum tersebut secara dinamis sesuai dengan laju kebudayaannya. Sebagian pihak menganggap the other laws bagian dari masa lalu, namun sebagian lagi menyatakan bahwa mereka tetap eksis hingga kini. Dan, sebagian lainnya menyatakan ada, namun semakin terkikis (Parsudi Suparlan, 1980; 20-23). Karena konsep 'unifikasi hukum' tetap didahulukan, maka keberadaan the other laws (hukum-hukum masyarakat lokal) menjadi terkendala. Kendalanya adalah: a) dari sisi masyarakat pemilik hukum lokal, mereka semakin tidak leluasa dalam mengimplementasikan hukumnya, b) dari sisi state, hukumhukum lain ditanggapi sebagai ganjalan yang dapat menghambat proses pembangunan (semesta) (Roger M. Keesing, 1992; 294). Benturan antara state law versus the other laws kemudian terjadi, dan dinamikanya terkadang tinggi, dan rendah. Konsep inilah yang dalam kajian antropologi hukum dikenal sebagai -konsep- terjadinya benturan antara legal centralism (pemusatan hukum) dengan legal pluralism (kemajemukan hukum). Yang satu dihadirkan, terutama, oleh hukum negara, dan yang lainnya oleh hukum masyarakat-masyarakat setempat.

\section{B. PEMBAhASAN}

Kajian Antropolgi Hukum di dalam perkembangan antropologi, masalah hukum sebenarnya juga sudah pernah ditelaah, walaupun di dalam suatu kerangka kebudayaan yang serba luas. Sarjana-sarjana antropologi seperti Barton, Radcliffe-Brown, Malinowski dan lainnya, pernah memusatkan perhatian pada hukum sebagai suatu gejala sosial-budaya. Sesudah embrio dari antropologi hukum timbul, maka pandangan para sarjana seperti Schapera, Gluckman, 
Hoebel, Bohannan, Pospisil, Nader dan lainnya mempunyai peranan besar di dalam perkembangan A.H. (Soekanto, 1984: 159-160). Menurut Ihromi (1986; 3) relevansi menelaah hukum dari segi antropologi, antara lain adalah:

(a). Berkenaan dengan masalah yang dihadapi oleh negara-negara berkembang (tentunya termasuk Indonesia) yang secara budaya bersifat pluralistis dalam cita-citanya mewujudkan unifikasi hukum atau modernisasi hokum

(b). berkenaan dengan kemungkinan munculnya masalah bila warga masyarakat dari lingkungan sukubangsa tertentu masih mempunyai norma-norma tradisional yang kuat dan Pandecta. Menuntut ketaatan mengenai hal-hal tertentu, sedangkan dalam norma hukum yang sudah tertulis dan berlaku secara nasional, hal-hal yang harus ditaati itu justru dirumuskan sebagai hal yang terlarang. Secara faktual, masalah-masalah yang dirumuskan ke dalam dua point utama itu sudah terjadi, baik berkenaan dengan munculnya konflik horisontal di pelbagai wilayah, pertikaian antara state (maupun pemda) dengan masyarakat, maupun antar kelompok masyarakat sendiri.

Hukum, menurut Benda-Beckmann (1979; 113-114) adalah suatu cara khusus untuk membatasi otonomi anggota-anggota masyarakat. Kebanyakan penulis menyetujui bahwa hukum adalah suatu bentuk pengawasan sosial, itulah mengapa secara esensial sifatnya normatif, dan hal itu merujuk pada apa yang disebut (sebagai) konsepsi-konsepsi yang obyektif. Implikasi pendekatan semacam ini adalah: bahwa hukum memberi input kepada pranata pengendalian sosial (apapun variant-nya) dan kemudian kepada rujukan berpikir masyarakat, dan sebaliknya. Hukum, di sisi lain, dapat pula menyebabkan perubahan perangkat berpikir, dan rujukan kemasyarakatan lainnya atau dikenal dalam sosiologi hukum sebagai "law as tool of social engineering". Namun, bila kesemua hal itu berubah (dan pada kenyataannya memang selalu demikian), maka hukum pun 
berubah mengikuti perubahan masyarakat dan lingkungannya. Pendekatan antropologi (hukum) sengaja menggeser pusat perhatian dari aturan-aturan kepada individu atau manusia sebagai aktor yang dalam mengambil keputusan mengenai perilakunya dihadapkan kepada tuntutan-tuntutan dari tatanan hukum yang dihadapinya (Ihromi, 2000: 3).

Sejalan dengan itu, Spiertz dan Wiber (1979: 3) menegaskan, bahwa: "But to study the real position of people in relation to law requires a different methodological approach from that used in traditional legal studies. The focus have to swift away from law as a codified or customary set of rules and turn instead to the individual who stands at the intersection point of many different legal domains (dikutip dari Ihromi, 2000). Kajian yang diusulkan tersebut lazimnya disebut sebagai kajian terhadap gejala hukum empiris (law in action). Dengan demikian, hukum dalam lingkup kajian Antropologi Hukum (selanjutnya ditulis A.H.) ditanggapi sebagai gejala empirik yang terjadi dalam kehidupan masyarakat. Hukum dalam konteks ini tidak ditanggapi seperti halnya para yuris mengkaji hukum (secara dogmatik). Secara umum metode AH adalah sebagai berikut:

(a). deskriptif - yakni pemerian gejala hukum empirik dalam masyarakat yang diteliti

(b). ideology (menelusuri aturan normatifnya)

(c). Telaah kasus (case study method), ditambah dengan metode komparasi (perbandingan).

Metode yang satu ini mendorong, antara lain diberlakukannya konsepsi cultural relativism(relativisme budaya).Selain metode di atas, dapat ditambahkan pendekatan historis yang mempelajari perilaku manusia dan budaya hukumnya dengan sudut proses sejarah (Hadikusuma, 1992: 9).Berikut ini akan dijabarkan, dianalisis, dan diulas beberapa pendekatan yang digunakan dalam sejarah perkembangan sub disiplin antropologi hukum dalam mengkaji hubungan hukum 
dengan masyarakat dan kulturnya. Mulanya kajian A.H. dimulai dengan mengkaji hal-hal besar, misalnya evolusi hukum (secara umum), sebut saja sekedar contoh kajiannya J.J. Bachofen tentang evolusi hukum (dalam bukunya das muterrecht). Dalam buku itu, Bachofen menjabarkan tahaptahapan evolusi hukum pada pelbagai masyarakat. Landasan kajiannya seringkali disebut sebagai "armchair theory" (kajian yang bukan berasal dari data primer atau field research). Kritik yang kemudian muncul adalah: sifat kajian mereka-mereka ini tergolong ke dalam "conjectural history" ("sejarah rekaan"). Mengapa demikian? Karena biasanya kita akan sulit menemukan kasus-kasus masyarakat seperti yang digambarkan oleh mereka (biasanya secara evolutif dan berkembang linier). Namun demikian, hasil karya mereka, atau setidaknya konsep-konsepnya justru mendorong - langsung maupun tidak - pihak lain menjadi tertarik dan mengkajinya secara lebih mendalam dan kritis.

Selanjutnya, ada ahli yang mengupayakan pendefinisian hukum secara lebih spesifik, misalnya Radcliffe-Brown, Max Gluckman, E. Adamson Hoebel, dan lainnya. Max Gluckman mendefisinikan hukum sebagai: aturan abstrak yang ditegakkan oleh lembaga formal. Hal ini sejalan dengan Radcliffe-Brown yang menerapkan fenomena hukum Barat pada masyarakat nonBarat. Definisinya tentang hukum (yang dikutipnya dari Roscoe Pond) adalah: "suatu pengendalian sosial yang dilakukan dengan perantaraan penerapan secara sistematis dari kekuatan fisik suatu masyarakat yang terorganisir secara politis" (Soekanto et al., 1984: 5). Definisi semacam ini, menurut beberapa ahli, membuat beberapa masyarakat tradisional - yang tidak memiliki kekuataan fisik yang terorganisir secara politis - menjadi tidak memiliki hukum. Padahal, mereka itu hidup dengan damai dan tertib ketika itu. Sementara, definisi yang mengidentikan hukum sama dengan adat (misalnya oleh Malinowski) telah membuat batasan, cakupan maupun gejala hukum menjadi tidak lagi jelas. Padahal, aturan-aturan hukum berbeda 
dengan aturan-aturan (Van Baal, 1988; 59).Binding obligations itulah yang menjadi esensi dari apa yang dapat dinamakan undang-undang. Binding obligations itu dijadikan dasar pada ketentuan fundamental bagi setiap masyarakat, yaitu timbalbalik. Lainnya, oleh karena aturan-aturan tersebut dirasakan dan dianggap sebagai kewajibankewajiban seseorang dan hak-hak dari fihak lain (Soekanto, 1984: 1).

Definisi lain adalah dari E. Adamson Hoebel (1954; 61), yaitu: A social norm is legal if its neglect or infraction is regulary met, in threat or in fact, by the application of physical force, by an individual or group, possessing the socially recognized privilege of so acting. Definisi ini mengandung hal-hal: a) tindakan yang melanggar aturan, b) akan ditindak secara teratur melalui sanksi c) oleh pihak yang berwenang. Definisi ini mirip dengan definisinya Radcliffe-Brown. Pendefinisikan tersebut rata-rata dilandasi oleh (sebutlah secara ringkas) sebagai pendekatan “struktural fungsional”dalam menelaah hukum. Menurut Radcliffe-Brown, masyarakat itu taat hukum karena adanya sanksi yang ditegakkan oleh lembaga resmi yang berwenang untuk itu. Lalu, ketika ada pertanyaan bagaimana dengan ketaatan yang terjadi pada masyarakat tradisional yang tidak memiliki "lembaga-lembaga penegakan hukum khusus"? Menurutnya, pada mereka ada potensi "kecenderungan misterius untuk taat". Namun, Malinowski menyatakan, hukum ditaati karena prinsip "give and take" (principal of reciprocity) yang berlaku dalam masyarakat (case studynya mengenai masyarakat Trobriand yang masih homogen ketika itu).Kritik yang diarahkan ke pendekatan yang termasuk ke dalam "struktural fungsional" antara lain adalah:

(1) Pendekatan lazim menggambarkan kebudayaan dan pranata sosial sebagai sesuatu yang "bulat", konstan dan memiliki pola yang jelas. Kenyataannya, kebudayaan dan pranata sosial selain sering mengalami konflik juga selalu berubah,

(2) pendekatan ini juga tidak mempertimbangkan adanya pluralisme budaya 
(3) kurang mempertimbangkan struktur sosial-budaya makro (dikutip dari Soehendera, 1989; 23-35). Pada titik ini mulailah perhatian kajian beralih bukan saja terhadap hukum hukum pada institusi modern, seperti negara, namun juga hukum masyarakat lainnya.

Salah satu batasan hukum yang cukup sering dikutip adalah yang disebut oleh Leopold Pospisil sebagai "attributes of law". Dia tidak secara langsung mendefinisikan hukum, namun memaparkan ciri-cirinya, yaitu: a) atribut otoritas, b) atribut penerapan secara universal, c) atribut obligatio dan d) atribut sanction. Konsep atribut hukum ini muncul dari hasil telusuran komparatif Pospisil atas pelbagai sistem hukum masyarakat-masyarakat yang dikajinya. Definisi, batasan atau atribut hukum yang disusun oleh para ahli tersebut berasal dari kajian komparasinya antara berbagai sistem dan proses hukum dari pelbagai masyarakat dan kebudayaan. Dengan kata lain, benih-benih perhatian akan kemajemukan kemudian bersemai (Soekanto et.al, 1994: 47). Pendekatan berikutnya yang kemudian beberapa bagiannya hingga kini masih diterapkan oleh banyak pengkaji antropologi hukum adalah: pendekatan terhadap penyelesaian sengketa (trouble cases). Pendekatan itu, umumnya, menelusuri sebab-sebab sengketa, pihak-pihak yang terlibat dan bagaimana penyelesainnya (termasuk siapa yang menyelesaikan, dan bagaimana sanksi yang diterapkannya). Sengketa itu hal yang melekat pada hubungan sosial, sehingga: a) bila hubungannya erat, maka penyelesaiannya cenderung damai (“win-win solution"); b) bila hubungannya renggang, maka penyelesaiannya cenderung adjudication (semacam win - loose solution). Dalam konteks ini, juga ditelaah mengenai lembaga hukum yakni: lembaga yang digunakan oleh warga untuk menyelesaikan sengketa yang timbul di antara para warga dan merupakan alat untuk tindakan balasan (counteract) setiap penyalahgunaan yang menyolok dan berat dari aturan yang ada pada lembaga lain dalam masyarakat. Tujuan menelusuri proses sengketa adalah untuk menemukan "intisari” hukum. Berbagai kajian penyelesaian sengketa dari 
pelbagai masyarakat dan kebudayaan kemudian diungkapkan dan ditelusuri. Karena penggunaan metode komparasi untuk berbagai penyelesaian sengketa semakin sering dan mendalam, akibatnya unsur-unsur kemajemukan pun semakin terpupuk (Dahrendorf, 1959: 209).

Mengenai konflik (conflict), Nader \& Todd (1978: 14-15), menganalisis tiga tahapan dari pertikaian (dispute): a) keluhan atau tahapan pra-konflik, dimana orang merasa diperlakukan tidak adil, b) tahapan konflik (conflict), dimana pihak yang dirugikan bertikai dengan pihak lain, dan c) tahap sengketa (dispute), dimana konflik meningkat ke arah konfrontasi publik karena melibatkan pihak ketiga. Mode-mode penanganan sengketa sangat bervariasi tetapi dapat diklasifikasikan ke dalam suatu prosuder yang bersifat umum (Gulliver, 1963; Colliner, 1973). Beberapa berupa penanganan dyadic (dua arah), seperti negosiasi yang mencakup dua pihak saja, yang mengembangkan aturan-aturannya sendiri dan mencapai kesepakatan melalui kompromi. Namun banyak bentuk dari penyelesai sengketa adalah triadic dan melibatkan pihak-pihak ketiga. Peran dan kekuasaan dari pihak ketiga itu tergantung pada struktur dari proses resolusinya. Mediasi, merupakan proses yang bersifat mendamaikan (conciliatory), pihak ketiga membantu dua pihak yang bersengketa mencapai suatu penyelesaian tetapi tidak memiliki otoritas untuk memaksa salah satu pihak. Dalam arbitrasi, pihak-pihak yang bersengketa sepakat pada tingkat yang lebih tinggi, untuk menerima keputusan pihak ketiga sebagai hal yang mengikat. Dalam ajudikasi, negara memberi kuasa (kepada) hakim untuk membuat keputusan yang mengikat tanpa harus mempertimbangkan persetujuan para pihak yang bersengketa (Barfield, 1997: 29). Varian dari pendekatan proses penyelesaian sengketa antara lain adalah pendekatan yang disebut oleh van Velsen (1967) sebagai "situational analysis" atau yang terlebih dulu diperkenalkan oleh Max Gluckman (1961) sebagai extended-case method (studi kasus yang diperluas). 
Tujuan pendekatan ini, menurut van Velsen adalah: untuk memberi ilustrasi mengenai keteraturan tertentu dalam proses sosial, dan bukan untuk menyoroti sifat-sifat khusus perorangan. Kajian Situational analysis adalah mengenai: catatan-catatan tentang situasi-situasi yang aktual dan perilaku tertentu. Analisis situasional ini, menurut penulisnya, bertekanan pada proses, studinya mengarah pada masyarakat yang tidak stabil dan tidak homogen. Asumsi pentingnya: bahwa norma-norma dari masyarakat tidaklah merupakan totalitas yang konsisten dan koheren. Sebaliknya, norma-norma tersebut sering terumus secara kabur dan saling tidak sesuai. Maka, kajian mengenai norma-norma yang saling berbeda dikaitkan dengan konflik menjadi sorotan utamanya. Kembali lagi terlihat bahwa benih-benih dan pandangan tentang kemajemukan semakin menegas di sini. Penelitian - mengenai penyelesaian sengketa - selanjutnya menganjurkan untuk berfokus pada wilayah urban dalam masyarakat industri modern yang jarang terikat bersama oleh jaringan akrab hubungan sosial dan yang rupanya bisa (lebih) memadai dalam membantu perkembangan bentuk penyelesaian sengketa konsiliatori yang dipertimbangkan oleh Gluckman (Merry \& Milner, 1993; Barfield, 1997: 73).

Kritik terhadap pendekatan proses penyelesaian sengketa ini adalah: a) upaya kompromis pada masyarakat yang berhubungan sosial erat (win-win solution) tidaklah selalu terjadi. Kompromi terjadi, biasanya karena ada kondisi keterbatasan sumbersumber daya, b) usaha untuk mencari keadilan dan pembalasan sulit dibuktikan, orang-orang lebih menggunakan prosedur lebih didasari oleh pilihan-pilihan yang rasional; c) pendekatan ini mengabaikan perubahan sejarah dan hubungan kekuasaan, serta menolak pengaruh struktural yang lebih luas (Barfield, 1997). Sementara itu, konflik (conflict) yang terjadi, pada kenyataannya tidak selalu menimbulkan hubungan-hubungan sosial yang disfungsional, terkadang konflik justru berfaedah untuk memelihara suatu hubungan sosial (Coser, 1964: 47; Coser, 1957: 227). Dan tidak semua konflik 
kemudian menjurus ke perkara hukum (karena adanya ancaman disintegrasi sosial atau motif lainnya). Selain pendekatan di atas, terdapat pula pendekatan trouble-less cases(Holleman, 1986; 65). Pendekatan ini, ringkasnya menyatakan bahwa dalam proses hukum sehari-hari yang lebih banyak terjadi bukanlah kasus sengketa, namun justru proses hukum non-sengketa (misalnya saja: proses perkawinan, jual-beli dan lainnya). Proses seperti ini, walaupun tidak harus melalui proses sengketa, tetap saja merupakan proses hukum penting karena di dalamnya tercermin aturan-aturan (normatif) maupun prakteknya sehari-hari. Gambaran semacam ini ikut "membulatkan" gambaran sistem hukum pada masyarakat yang ditelaah. Interaksi (hukum) non sengketa juga bisa terjadi pada pihak-pihak yang berbeda sistem hukumnya. Dan seringkali mereka juga tidak bersengketa.

Pendekatan selanjutnya adalah yang populer dengan sebutan 'Kemajemukan Hukum” (legal pluralism) (lihat misalnya Masinambow [ed], 2000; Irianto, 2003). Konsep ini menyatakan bahwa selain state law, terhadap sistem-sistem hukum lain yang juga aktif berfungsi dalam pelbagai lapisan dan kelompok masyarakat. Benturan antara implementasi state law dengan sistem-sistem hukum lain itulah yang menjadi konsentrasi pendekatan yang satu ini. Pendekatan ini mulai populer di tahun 1980an, dan hingga kini masih diminati oleh banyak pengkaji antropologi hukum. Pengertian kemajemukan hukum, ringkasnya adalah: (a). Dalam dunia pragmatis setidaknya ada dua sistem aturan yang terwujud; (b). bagaimana hukum berperan dan menyesuaikan diri dalam kondisi kemajemukan budaya.Pendekatan yang satu ini, lazimnya dikaitkan dengan pemahaman mengenai "plural society" (masyarakat majemuk) yang dijabarkan sebagai: masyarakat yang terdiri dari populasi multi etnik yang di dalamnya terjadi suatu kegiatan ekonomi yang tersebarkan dan aturan politik yang tersentralisasi oleh salah satu kelompok tertentu (Barfield, 1997: 68). Pada masa Orba, gambaran plural society memang lebih nampak. Pola patron-client relationship dikembangkan sedemikian rupa untuk lebih mencapai tujuan tertentu. 
Pola ini digunakan untuk melingkupi hubungan antara berbagai pihak yang majemuk, sehingga kadangkala memunculkan benturan. Kajian Kemajemukan Hukum dapat dikaitkan dengan pendapatnya Lawrence Friedman $(1975 ; 22)$ yang menyatakan bahwa hukum itu terdiri dari tiga komponen, yakni: (a). legal Substance: norma-norma, aturan-aturan yang digunakan secara institusional, dan pola perilaku para pelaku dalam sistem hukum; (b). Legal structure: lembagalembaga hukum; (c). Legal culture: kebiasaan, pandangan, cara bertindak dan berpikir yang dapat mempengaruhi kekuatan-kekuatan sosial. Ketiga komponen itu dapat dikaji kemajemukannya semuanya. Namun, bisa saja salah satu komponennya saja. Masing-masing komponen itu, bila dikaji, kelak akan memunculkan dampak maupun konteks yang berbeda-beda. Yang jelas, para ahli antropologi hukum menekankan bahwa hukum buatan negara hanyalah salah satu dari sistem pengaturan yang relevan untuk menjadi pedoman berperilaku warga masyarakatnya (Ihromi, 2000: 4).

\section{PENUTUP}

\section{A. Kesimpulan}

Pengkajian Antropologi Hukum telah memberikan telaah akan hasil kreasi, distribusi dan transmisi hukum yang ada. Kajian mengenai bagaimana kekuasaan hukum berproses dan memberi dampak dalam masing-masing masyarakat. Selanjutnya akan menampilkan bagaimana feed back dan pengaruh masyarakat-masyarakat terhadap kekuasaan hukum tersebut. Kemajemukan hukum yang ada di Indonesia dewasa ini merupakan soal tersendiri mengingat otetisitas Antropologi Hukum yang sejak lama menempatkan dan menghargai the other lawssecara proporsional dan kontekstual. Dengan demikian para pengkaji antropologi hukum ditantang untuk memberikan kontribusi bagi perkembangan hukum di Indonesia, khususnya terkait dengan korelasi positif the other laws dengan state laws. 


\section{DAFTAR PUSTAKA}

Gokma Toni Parlindungan S, Asas Nebis In Idem Dalam Putusan Hakim Dalam Perkara Poligami Di Pengadilan Negeri Pasaman Sebagai Ceriminan Ius Constitutum, Volume 2, Nomor 1, 2020.

Gokma Toni Parlindungan S, Pengisian Jabatan Perangkat Nagari Pemekaran Di Pasaman Barat Dalam Rangka Pelaksanaan Otonomi Daerah, Ensiklopedia Of Journal, Vol 1 No 2 Edisi 2 Januari 2019,

Harniwati, Peralihan Hak Ulayat Menurut Undang-Undang Nomor 18 Tahun 2004, Volume 1, Nomor 3, 2019.

Jasmir, Pengembalian Status Hukum Tanah Ulayat Atas Hak Guna Usaha, Soumatera Law Review, Volume 1, Nomor 1, 2018.

Jumrawarsi Jumrawarsi, Neviyarni Suhaili, Peran Seorang Guru Dalam Menciptakan Lingkungan Belajar Yang Kondusif, Ensikopedia Education Review, Vol 2, No 3 (2020): Volume 2 No.3 Desember 2020

Mia Siratni, Proses Perkawinan Menurut Hukum Adatdi Kepulauan Mentawai Di Sebelum Dan Sesudah Berlakunya Undang-Undang Nomor 1 Tahun 1974 Tentang Perkawinan, Ensiklopedia Of Journal, Vol 1 No 2 Edisi 2 Januari 2019,

Remincel, Dimensi Hukum Pelanggaran Kecelakaan Lalu Dan Angkutan Jalan Lintas Di Indonesia, Ensiklopedia Social Review, Volume 1, Nomor 2, 2019.

R Amin, B Nurdin, Konflik Perwakafan Tanah Muhammadiyah di Nagari Singkarak Kabupaten Solok Indonesia 2015-2019, Soumatera Law Review, Volume 3, Nomor 1, 2020. 